\title{
Maklews Etnic Woman's Participation on Environmental Management
}

\author{
Godefridus Samderubun ${ }^{1 *}$, Ransta Lekatompessy ${ }^{1}$, Apolus Betaubun ${ }^{1}$, David Layan ${ }^{1}$ \\ ${ }^{1}$ Department of Public Administration, Faculty of Social And Politic, University of Musamus
}

\begin{abstract}
Woman have strong links with the environmental. In his role as manager of the household, they are more interacting with the environmental and natural recousces. The efforts were made by Maklew's Woman with cultivated an attitude of assistance and keep maintain their environmental. So the worked together in their culture like kayau in their countryside stil remained until now. But effort of Maklew's woman to keep maintained the local wisdom "kayau" for environmental management, there has challenges. One of the interesting things to be examined is that of the management of the environment and resources. Maklew is the tribe with a practice of very strong patriarchy. The position of women in Maklew etnic is assumed as "second person". Specifically in the culture ofetnic maklew, the position of women is considered very important. Women and the land are symbolized as the origin and the source of life, as the giver of life. The study of Maklw's Womans Participation for environmental management use the feminism and ecofeminism theory and exchanged theory where there are several indicators related by Kayau as a local wisdom to environmental management. The indicators or prepositions are role of division, acces of control and decision making making with kayau perpective. This research was carried out in Wasur village, which is one of villages with the population of indigenous of Marind, located in Merauke, bordering Papua New Guinea. This research includes of qualitative and descriptive approach. Statistic collected is done by observation method, intervieuw using snowball sampling method. Data analysis in this research by descriptive analisys. As the result in the research showing that Maklew's Woman in participation on environmental management in Wasue Village still strong and kept well. There was show from mutual cooperation from Maklew's woman on environmental management with Kayau that still continues. All the people especially Maklew's Woman still kept the local wisdom Kayau in their environmental management activity.
\end{abstract}

Keywords : Woman; kayau environment management.

\section{Introduction}

Women have an important role in maintaining the continuity of development programs on an ongoing basis. Women as human resources is a basic construction in order to be always capable of being the subject in the global scene so it's not only become the object of development. The fact shows that the execution of development initiated during this less in favour of women, even tend to marginalize women. The marginalization of women consciously or unconsciously taken for granted by women as the nature which has been inherent in women. Women are excluded from the opportunity to improve the quality of life, such as the opportunity to earn an increase in knowledge, skills, education, capital, and health services. Low quality resources of women because women don't have opportunities to enhance quality so that it becomes a way of justification will powerlessness of women. Reasons of empowerment to make a lot of women are not involved in the various activities in the community. Women were considered less capable to bear the burdens and responsibilities in society. Enhancing the role of women is a step that needs to be concentrated in order for women to be able to play a role as opposed to type in any of the activities in the community.

Indigenous Malind Anim especially ethnic Maklew who dwelt in Kampung Wasur, Merauke, culturally regulated by the patriaki undiluted system, groups of men occupy the highest positions in cultural status. Recognition of the role of women organized in culture yet the portion of responsibility in the custom is not equivalent to a group of men. In performing everyday activities, namely activities of social, economic and cultural centre of women's groups always involved but not authorized in decision making. More women play a role in the management of the domestic space and men tend to 
bertangunggjawab on public space. In some previous research noted that men and women have difference's role in environmental and natural resource management. The importance of reviewing the gender perspective in environmental management in the area of customs Malind Anim so that women can also involved participation in support of sustainable development in the Regency of Merauke. The value of the inequality towards the empowerment of women is a result of the dominance of men or the influence of patriarchy. However, if the terms of the cultural Outlook of Malind Anim regarding land which is considered as the mother then women in culture is the source of life of indigenous peoples Malind Anim, as a guard and a nurse lives, both human life and life and the harmony of nature. Tasks and malind Women as carers and nurses is known by the name kayau, or Malind meaning "guard" and nursing. This means that environmental management in the role of women and men should be equal so that indirectly can increase the sustainability of the natural creation. With regard to the formulation of the problem is how the role of women in the management of local indigenous knowledge-based environment kayau?.

This research aims to know the role of women in the management of resources or the environment in the culture of the ethnic Maklew in particular Malind.

\section{Method}

\subsubsection{Types and sources of Data}

The required data in this research is the primary data and secondary data. The primary data consist of local wisdom in the management of land, forests and environment data retrieved memalui hands-on experience and in-depth interviews. The secondary data were obtained from the village apparatus as well as a review of the literature. [1] says that the data analysis used are descriptive analysis. According to Nasir (2003) in [7] the descriptive analysis of the objectives is to make the description, picture in a systematic, factual and accurate regarding the facts, properties and relationships between phenomena investigated. Here the author describes the local wisdom kayau, in General and in particular know and understand about how the position of women in the local wisdom Kayau in aspects of the Division of roles, access and control and decision making.

\section{Results}

\subsubsection{Local wisdom "Kayau" in the tradition of Ethnic Maklew.}

Local wisdom built from social values overriding in the structure of social community on their own and serve as guidelines for controllers and signs to behave in various dimensions of life good when dealing with sesame or nature (Santoso,2009). The local wisdom is also a form of environmental wisdom that exists within the life of society in one place or area. This means that the local wisdom refers to the locality and community. (Suhartini 2009). Different views dating from [6], the local wisdom is all forms of belief knowledge, understanding or insight and custom or ethics that guide the behavior of the manusiadalam life in the middle of the ecological community. The view above semakimn confirms that the local wisdom is of capital importance in the management of natural resources and the environment. Maklew Ethnic community in Kampung Wasur is one of the sub Tribe of the ethnic Malind Anim in southern New Guinea.

Just as ethnic-ethnic ethnic other then Maklew also a community a very strong cultural identity include linguistic, religious and familial pattern system. There is a values and traditions held in the ethnic community Maklew i.e. kayau tradition. Kayau tradition is specifically set about relationships and human behaviour in relationship to nature or the environment around them. Literally "kayau" translated as "caring" or "keep" nature. Each Member of the tribe Maklew are "keepers" and "nurse" nature or the environment. Therefore it is not justified if there are members of the Maklew damage or apply arbitrarily against nature. This is practical kayau tradition in every human action when doing activities like open farmland, patterns or tillage system. The interesting thing about this is Maklew ethnic diera already very modern with the science that's been ahead in farming technology but they still obedience to uphold the rules of customs inherited hereditary.

\subsubsection{Land Management}

The opening of the land in the Ethnic Culture Maklew should be based on a referral from an old Custom (parents who know and know the ins and outs of the land and the customary in kampung Wasur). Initially the land was opened to incur the landlord accompanied by Old customs. Then they opened the land is marked by an old custom, then by the Old custom of "informing" the land ancestors that were about to be opened as farmland. "Notice" that was given in the form of the form of words that conveyed in the language of the indigenous. The goal is to let you know so that in the process of cultivation is "no distractions". One of the important things that should be kept in the process of opening of this land is land, opened not with burned. Furthermore, in the opening of the land are not allowed to cut down trees that were already rather large. Only membabat 
allowed the tares or weeds. Furthermore, in the process opening the land too, there must be no impediments such as concerned violation of custom and others. The process of determining the land that must be opened, the quantity of land held by ethnic female Maklew. The men usually only plays a role in the opening of the land only, then the whole process of cleansing the land, planting, care until the harvest is done by women. This is because the presumption that women are closer to nature so it has immediacy because female characters who are able to care for and maintain than men. Men usually after opening the land, then it will return a more job-oriented masculinity such as hunting and others.

\subsubsection{The position of Women Maklew in Kayau}

\section{The Division of Roles}

Like all culture that embraced the doctrine of patriarchy, it is in the context of the Maklew tribe, a husband acts as the head of family who is in charge of a living to meet the needs of clothing, food and Board. However different in terms of the other. Based on the real results, it was found that pembagiana the role of tribal families that occur in Maklew as Tribe Marind at umunya is flexible or not rigid. In the context of resource management, especially in the local wisdom kayau, here the role of women is very important. Already explained above that due to the nature of women who like to keep and take care of, making women a role in the determination of land that will be open to the needs of the fields. Women who determine the land where the bias is opened or used and land which may refuses. If it is already defined then it should be followed, Maklew Ethnic Communities believe that what has been specified is already according to the wishes of the leuluhur. Once defined the old Customs then will deliver ' ancestral guard permission to permohona the land, and the land could be opened.

\section{a. Access and control}

Access and control is a way to assess how resources are allocated among men and women (the allocation of resources based on gender). Based on the results of the interview, the situation found that women's access to and control of the tribe Maklew in Kampung Wasur regarding utilization and use of resources in the fields of activities, ranging from clearing land, planting, menunggal, clean the grass, to harvest the results. In addition many of the women who sell vegetables and fruit, other results acquired from the forests, fields, or swamp or suangi around kampong. set it free of the reproductive role and the role of social/community management. Women's access to land against a pretty open, basically due to the custom of women are given equal opportunities with men in mastering the land, either by way of opening of forests, land use backup, inheritance, purchase, and borrowing. Access control in the family-owned Tribal maklew women pertain to land use tends to be quite large, since he was directly involved in the activities of the productive use of the land. Big or small, you access and control that are owned by women in the utilization of natural resources are influenced by several factors, among others: the social and cultural Conditions, still lack the bargaining position of women/female lack, Limitation women in the mastery of science and technology.

\section{b. Decision Making}

Currently there are still a lot of supposition that women have no role in decision making, both outside and in the household. The existence of gender bias is always positioned woman as someone who is weak and does not have power. Based on the norm that there is a saying that the most decisive in the decision making is the man (husband). It can not be denied again in the environment of society even in the tribe society of Maklew in Wasur Vilage. The Maklew woman role of in decision-making when viewed from the context of Kayau then only happens if the plant is grown for the need to eat like ubi-ubian etc. However, if the long-term plant-related then it's usually men who took the decision. Maklew, women only participate in decision-making if it is related to the family. However if it is associated with a resource, such as indigenous land, forest land, etc., then the woman Maklew have absolutely no access to engage in decision making. In the important deliberations or meeting to make a decision regarding the previous indigenous land, forests for example, women are indeed invited to attend, but they are not at all given the space to talk let alone took the decisions. The entire decision taken by men through customary Chair. Even such as proceeds from the sale of the land, all of which are governed by men. It is certainly because it is very concerned with a very strong patriarchal culture. Another impact is female Maklew have absolutely no access to the heritage of the land for example. The land was divided out of stock for men. Women were considered to be married and entered in the family lainsehingga she gets from her husband. Besides other factors that affect the role of women in decision-making, among others, the process of socialization, education, marital background, position in society, and other outside influences.

\section{Conclusion}

Based on the explanation that has been put forth above, it can be concluded that: 1st, Maklew tribe is still very strong holding fast to their culture and tradition, especially in terms of opening land and its management. Second, the position of women if seen from the aspect of the Division of roles, access and control and decision making is still very small or 
weak. Men are still very dominant and in decision making and access control in the management of forests and natural resources. Third, creating a gender equality in management of natural resources in particular in the Division of roles, access and control as well as decision making is not something easy to do. However, that does not mean it cannot be attempted. Natural resource management process insightful gender equality and justice needs to be improved because there is still a wide range of symptoms of gender bias. Men tend to still be placed on a more favorable position in the overall management of the resource. Need the effort and encouragement that is much harder to encourage gender equality in the management of natural resources. The function of women in family and gender sensitive yet fully mayarakat and load the gender equality concept will certainly influential in maintaining, d enhancing gender equality and justice in the process of natural resource management. So it is very necessary role of goverment as the agencies have the authority in making policy, in order to provide access and more in the management of natural resources for the sake of the realization of genderer equality. There is no denying that the construction is currently being implemented in Merauke, a major impact on the degradation of the quality of the environment of the community. Especially the development impact on the decrease of carbon. This is caused by more or less 3 things i.e. the opening of large-scale forest for Palm oil plantations, the opening of land or forest to agriculture, associated with whom he turned Merauke as national food Barn and burning forest undertaken by the community, either intentionally or unintentionally.

In the context of the issue then the Women of the tribe of Maklew can be instrumental in doing the protection of the forests and the land that became the source of their lives. It is also in accordance with the nature of the woman who is always caring and protecting. The trick is to do a dialogue and call upon decisionmakers/Government and people for the first; not solely pursue economic development that results in the destruction of forests. The opening of the Plantation is thousands of acres denuded forests into cause and replaced by plantations. Secondly, campaigning about replanting the forests that serve as the land. This aims to reduce the carbon that the higher due to deforestation.
Only in that way then the forests will continue to be revitalized so that deforestrasi can be reduced. Third, the proposed that there are penalties for the company, the individual who opened the land by burning, because the burning of forests will cause smoke and uncontrolled destruction of forests. All this can be championed by women, because women are the very parties harmed by the existence of damage to forests and the environment.

\section{Reference}

1. Bungin, 2011. Metodologi Penelitian Kualitatif. PT Raja Grafindo Persada Jakarta.

2. Rodda, 1994. Women and Environment. London: Zed Books Ltd.

3. Mitchel, Bruce 1997. Pengelolaan Sumberdaya dan Lingkungan. Jogyakarta: Gajah Mada University Press.

4. Budiman, Arif. 1985. Pembagian Kerja Secara Seksual. Jakarta: Gramedia.

5. Fakih. Mansour. 1997. Analisis Gender dan Transformasi Sosial. Jakarta: Insist Press.

6. Keraf, Sonny, A. 2003. Etika Lingkungan. Jakarta: Kompas.

7. Juslianty, 2012. Analisis Rencana Pemanfaatan Hutan Untuk pengembangan Hutan Tanaman Rakyat pada KPH Model Dampelas- Tinombo Desa Kambayang Kecamatan Dampelas, Skripsi. Fakultas Kehutanan, Universitas Tadulako, Palu.

8. Laksono, P. M. dkk. 2004. Ken Sa Faak. Jogyakarta: Insist Press.

9. Mellor, Marry. 1997. Feminism and Ecology. Cambridge: Polity Press.

10. Moleong, L. J. 1998. Metode Penelitian Kualitatif. Bandung: PT. Remaja Rosdakarya.

11. Naes, Arne. 1993. Ecology, Community and Lifestyle. Cambridge: Cambridge University Press.

12. Purba, Johnny (ed). 2005. Pengelolaan Lingkungan Sosial. Jakarta: Penerbit Obor.

13. Siombo, M.A 2011. Kearifan Lokal Dalam Perspektif HukumLingkungan. Jurnal. Jurusan Hukum Fakultas Hukum Universitas Tadulako.

14. Sajogyo. 1983. Peranan Wanita Dalam Perkembangan Masyarakat Desa. Jakarta: Rajawali Press.

15. Simantau, Meentje, dkk. 2001. Gender dan Pengelolaan Sumber Daya Alam. Jogyakarta: Galang Printika.

16. Warren, J. Karen. 1997. Ecofeminisme. Indiana: Indiana University Press. 